\title{
ASSESSMENT OF PHYSICOCHEMICAL AND SENSORY QUALITY OF BEEF PATTIES FORMULATED WITH PENNYROYAL (Mentha pulegium L.) POWDER
}

\author{
Farida Guliyeva, Sadettin Turhan* \\ Department of Food Engineering, Engineering Faculty, Ondokuz Mayis University, Samsun, Turkey
}

Received /Geliş: 06.01.2021; Accepted / Kabul: 21.04.2021; Published online / Online bask1: 10.05.2021

Guliyeva, F., Turhan, S. (2021). Assessment of physicochemical and sensory quality of beef patties formulated with pennyroyal (Mentha pulegium L.) powder. GIDA (2021) 46 (3) 739-750 doi: 10.15237/gida.GD21011

Guliyeva, F., Turhan, S. (2021). Yarpuz (Mentha pulegium L.) tozu ile formüle edilen sığır köftelerinin fizikokimyasal ve duyusal kalitesinin değerlendirilmesi. GIDA (2021) 46 (3) 739-750 doi: 10.15237/ gida.GD210118

\section{ABSTRACT \\ The present study was conducted to evaluate the physicochemical and sensory quality of beef patties containing different levels of pennyroyal powder (PP) during storage at $4^{\circ} \mathrm{C}$ for up to 9 days. The PP was added to patties at $0.75,1.5,2.25$, and $3.0 \%$ levels and compared to negative (without PP) and positive controls $(0.01 \%$ propyl gallate). The PP addition decreased the protein content and increased the ash content $(P<0.05)$. The PP inclusion improved cooking loss, but negatively affect the hardness and overall acceptability $(P<0.05)$. However, overall acceptability scores of patties containing up to $1.5 \%$ PP were similar to the negative and positive controls $(P>0.05)$. The $\mathrm{PP}$ incorporation improved the $\mathrm{pH}$, lipid, and color stability during the storage period $(P<0.05)$. Thus, the inclusion of $1.5 \% \mathrm{PP}$ could be recommended to retard the lipid and color oxidation of patties with minimal compositional, textural, and sensory changes. Keywords: Beef patty, pennyroyal, quality, storage stability \\ YARPUZ (Mentha pulegium L.) TOZU İLE FORMÜLE EDİLEN SIĞIR KÖFTELERİNİN FİZIKOKIMMYASAL VE DUYUSAL KALİTESINNINN DEĞERLENDİRÍLMESİ}

\section{ÖZ}

Bu çalışma, farklı düzeylerde yarpuz tozu (YT) içeren sığır köftelerinin $4{ }^{\circ} \mathrm{C}^{\prime}$ de 9 güne kadar depolama sırasında fizikokimyasal ve duyusal kalitesini değerlendirmek için gerçekleştirilmiştir. YT, köfte formülasyonlarına $\% 0.75,1.5,2.25$ ve 3.0 düzeylerinde ilave edilmiş ve gruplar, negatif (YT içermeyen) ve pozitif kontrol (\%0.01 propil gallat içeren) ile karşılaştırılmıştır. YT ilavesi protein miktarını düşürmüş, kül miktarını artırmıştır $(P<0.05)$. YT ilavesi pişirme kaybını azaltmış ancak sertliği ve genel kabul edilebilirliği olumsuz yönde etkilemiştir $(P<0.05)$. Bununla birlikte \%1.5'e kadar YT içeren köftelerin genel kabul edilebilirlik puanları, negatif ve pozitif kontrole benzer bulunmuştur $(P>0.05)$. YT ilavesi depolama süresince $\mathrm{pH}$, lipit ve renk stabilitesini geliștirmiștir $(P$ $<0.05)$. Böylece minimum bileşimsel, tekstürel ve duyusal değişikliklerle köftelerin lipit ve renk oksidasyonunu yavaşlatmak için \%1.5 düzeyinde YT kullanımı önerilebilir.

Anahtar kelimeler: Sığır köftesi, yarpuz, kalite, depolama stabilitesi

\footnotetext{
*Corresponding author / Yazışmalardan sorumlu yazar

$₫$ sturhan@omu.edu.tr (c) (+90) 362312 1919/1503

县 $(+90) 3624576034$
}

Farida Guliyeva; ORCID no: 0000-0002-5281-0270

Sadettin Turhan; ORCID no: 0000-0002-3510-4382 


\section{INTRODUCTION}

Minced meat products called beef patty, burger, or meatball are very popular foods among consumers of all age groups in many countries due to their easy preparation, attractive sensory properties, and low price (Selani et al., 2016; Hautrive et al., 2019; Öztürk and Turhan, 2020). However, the fact that these meat products often lack dietary fiber which should be present in a healthy diet (Öztürk and Turhan, 2020), and are exposed to apart from microbial spoilage, lipid oxidation during cold storage require them to be supplemented with different additives (Fernandez-Lopez et al., 2005; Juntachote et al., 2007). Because oxidative reactions in meat during processing and storage result in deterioration of color and sensory quality and decreased shelf-life (Fernandez-Lopez et al., 2005; Juntachote et al., 2006; Choe et al., 2011). Also, it can lead to the potential formation of toxic oxidation compounds (Juntachote et al., 2006). Although synthetic additives have been widely used in the meat industry to overcome these problems, the trend is to decrease their use because of the toxicity and carcinogenicity of such chemical additives (Fernandez-Lopez et al., 2005; Juntachote et al., 2006, 2007; Choe et al., 2011). Therefore, the addition of plant materials can provide dietary fiber, vitamins, and phenolic compounds and enhance oxidative stability.

Pennyroyal (Mentha pulegium) is an aromatic herb that belongs to the family Lamiaceae, is naturalized in America, and thrives in Western, Southern and Central Europe, Asia, Iran, Arab countries, and Ethiopia (Teixeira et al., 2012). It is a perennial, and herbaceous plant, which can reach up to half a meter in height (Gülçin et al., 2020). Its essential oil and dry parts have been traditionally used in medicine (digestive, liver and gallbladder disorders, amenorrhea, gout, colds, increased micturition, skin diseases, and abortifacient), gastronomy (culinary herb), aromatherapy, and cosmetics (Teixeira et al., 2012; Çelik et al., 2017). Recent research has shown that extracts of pennyroyal are an excellent source of phenolic compounds such as kaempferol-3-O-rutinoside, quercetagetin-3,6dimethylether, fumaric acid, chlorogenic acid, apigenin, and epicatechin, which are responsible for antioxidant capacity (Çelik et al., 2017; Gülçin et al., 2020). Despite the high phenolic content and antioxidant capacity of pennyroyal, there are limited studies on the use of its essential oil, powder, and extracts in foods. For example, Kamkar et al. (2010) reported that water extract of pennyroyal is a potent antioxidant for sunflower oil during storage.

Unfortunately, there are no studies about the application of pennyroyal essential oil, powder, or extracts in meat systems. Therefore, this study aimed to assess the effect of the use of pennyroyal powder on physicochemical (proximate composition, cooking loss, texture, $\mathrm{pH}$, TBARS, and color) and sensory quality of beef patties during cold storage $\left(4^{\circ} \mathrm{C}\right)$.

\section{MATERIAL AND METHOD}

\section{Materials}

Pennyroyal (Mentha pulegium L.) plants were collected from their natural habitat, Baku, Azerbaijan, in early July 2019. The plants were dried in a dark place at room temperature, powdered using an electrical device, and passed through a $0.5 \mu \mathrm{m}$ sieve. The obtained pennyroyal powder (moisture 11.80\%) was kept in the refrigerator until use. The minced beef (moisture $61.90 \%$, protein $21.56 \%$, fat $14.54 \%$, and ash $1.00 \%$ ) and beef fat (moisture $8.05 \%$, fat $87.65 \%$ ) were supplied from a butcher shop in Samsun city, Turkey. Food grade propyl gallate (PG) was purchased from Merck (Darmstadt, Germany). Unless otherwise stated, all chemicals used were of analytical grade.

\section{Total phenolic content and antioxidant activity of the pennyroyal powder Extraction procedure}

For the extraction of phenolic compounds in pennyroyal, $5 \mathrm{~g}$ of pennyroyal powder was mixed with $20 \mathrm{~mL}$ of $80 \%$ methanol aqueous solution, placed in an ultrasonic bath (Bandelin Sonorex, RK 100, Germany), and sonicated at room temperature for $15 \mathrm{~min}$. At the end of sonication, the suspension was left in dark at room temperature for $12 \mathrm{~h}$ and filtrated through filter paper (Whatman No. 1, Maidstone, UK). The 
obtained extract was used for both the total phenolic content and antioxidant activity determinations.

\section{Determination of total phenolic content}

Total phenolic content was determined following the method described by Singleton and Rossi (1965) with some modifications. Briefly, $20 \mu \mathrm{L}$ of the diluted pennyroyal extract was transferred to test tubes and mixed with diluted (1:10 with water) Folin-Ciocalteu reagent $(100 \mu \mathrm{L})$, distilled water $(1580 \mu \mathrm{L})$, and $7.5 \% \mathrm{Na}_{2} \mathrm{CO}_{3}$ solution $(300$ $\mu \mathrm{L})$. After incubating the test tubes in dark at room temperature for $2 \mathrm{~h}$, the absorbance $(760$ $\mathrm{nm}$ ) of the solutions was measured. The total phenolic content was expressed as $\mathrm{mg}$ of gallic acid equivalent (GAE)/g sample.

\section{2,2-diphenyl-1-picrylhydrazyl (DPPH) radical scavenging activity}

The DPPH scavenging activity assay was carried out following the protocol described by Nakajima et al. (2004), with a slight modification. Briefly, 50 $\mu \mathrm{L}$ of the diluted pennyroyal extract was added to $1 \mathrm{~mL}$ of DPPH methanol solution $(100 \mu \mathrm{M})$. After incubating in dark for $2 \mathrm{~h}$, the absorbance readings were performed at $517 \mathrm{~nm}$. The results were expressed using Trolox as standard: mmol Trolox equivalents (TE)/g sample.

\section{Ferric reducing antioxidant power (FRAP)}

The FRAP assay was performed according to the methodology, described by Gao et al. (2000). Briefly, $50 \mu \mathrm{L}$ of the diluted pennyroyal extract was mixed with $0.95 \mathrm{~mL}$ ferric-2,4,6-tripyridil-striazine (TPTZ) reagent (which was done by mixing $300 \mathrm{mM}$ acetate buffer, $\mathrm{pH}$ 3.6, $10 \mathrm{mM}$ TPTZ in $40 \mathrm{mM} \mathrm{HCl}$ and $20 \mathrm{mM} \mathrm{FeCl}_{3}$ at the ratio 10:1:1, respectively). After incubating at room temperature for $5 \mathrm{~min}$, the absorbance readings were performed at $593 \mathrm{~nm}$. The results were expressed using Trolox as standard: $\mathrm{mmol}$ TE/g sample.

\section{Preparation of beef patties}

Two separate trials were performed on different days using different minced meat and beef fat but the same ingredients, and $6 \mathrm{~kg}$ of beef patties were manufactured for each trial. Six different batches of beef patties were produced as follows: 1) CON - negative control $(78.50 \%$ minced beef $+20 \%$ beef fat $+1.5 \%$ salt); 2) PG - positive control (78.49\% minced beef $+20 \%$ beef fat $+1.5 \%$ salt $+0.01 \%$ PG); 3 ) P075 (77.75\% minced beef + $20 \%$ beef fat $+1.5 \%$ salt $+0.75 \%$ pennyroyal powder); 4) $\mathrm{P} 150$ (77.00\% minced beef $+20 \%$ beef fat $+1.5 \%$ salt $+1.5 \%$ pennyroyal powder); 5) P225 (76.25\% minced beef $+20 \%$ beef fat + $1.5 \%$ salt $+2.25 \%$ pennyroyal powder); 6) P300 $(75.50 \%$ minced beef $+20 \%$ beef fat $+1.5 \%$ salt $+3.0 \%$ pennyroyal powder). All batches were mixed for 10 min to obtain a homogenous mass, weighed into $\sim 25 \mathrm{~g}$ portions, and shaped by hand with gloves. The final products with a mean of 50 $\mathrm{mm}$ diameter and $10 \mathrm{~mm}$ thickness were aerobically packaged in polyamide bags with an oxygen transmission rate of $52.4 \mathrm{~cm}^{3} / \mathrm{m}^{2} / 24 \mathrm{~h}$ at $1 \mathrm{~atm}$ and $23^{\circ} \mathrm{C}$ and stored at $4 \pm 1{ }^{\circ} \mathrm{C}$ home-type refrigerator for 9 days. Proximate composition, cooking loss, texture parameters, and sensory attributes of samples were evaluated at the initial day of storage, while the $\mathrm{pH}$, thiobarbituric acid reactive substances (TBARS), and color parameters were analyzed on days $0,3,6$, and 9 of storage.

\section{Determination of proximate composition, cooking loss and texture parameters}

The proximate composition (moisture, protein, fat, and ash) of the beef patties and raw materials was determined according to the official standard method (AOAC, 2000). For cooking loss, beef patties were cooked in a preheated electrical grill (Arçelik Midi Fırın, Turkey) for a total of 8 min, 5 min one side and $3 \mathrm{~min}$ the other side. The weight of three meatballs per batch was measured at room temperature, before and after cooking to calculate the percentage of cooking loss, and the results were expressed in percentage $(\%)$.

Texture parameters of the beef patties were determined at $25{ }^{\circ} \mathrm{C}$ using a Texture Analyzer (TA-XT Plus, Stable Micro Systems, UK) equipped with an aluminum cylindrical probe (model P/50R). For analysis, samples were placed on the center of the TPA platform and compressed twice to $60 \%$ of their original height. The conditions were as follows: pre-test speed 2.0 
$\mathrm{mm} / \mathrm{s}$, post-test speed $5.0 \mathrm{~mm} / \mathrm{s}$, test speed 5.0 $\mathrm{mm} / \mathrm{s}$, and the testing interval $5 \mathrm{~s}$. The values for hardness $(\mathrm{N})$, springiness $(\mathrm{mm})$, cohesiveness, and chewiness (N.mm) were calculated from the curves provided by the equipment (Öztürk and Turhan, 2020).

\section{Evaluation of sensory attributes}

Sensory properties (appearance, flavor, juiciness, and tenderness) of the beef patties were evaluated by an experienced panelist group of 10 members from the staff and graduate students on the initial day of storage. All sensory work was carried out in the sensory evaluation room under fluorescence lighting to minimize the scope of errors. The cooked samples were cooled to room temperature, cut into blocks, coded with a threedigit random number, and served to each panelist. The panelists evaluated the samples randomly and after rating each sample, rinsed their mouths with water and waited 1-2 min before evaluating the next sample. A 9- point hedonic scale was used to assess appearance and flavor $(1=$ undesirable to 9 = desirable), while a 9- point descriptive scale was used to assess juiciness $(1=$ dry to $9=$ juicy $)$ and tenderness $(1=$ tough to $9=$ tender $)$. The overall acceptability was calculated taking into account appearance, flavor, juiciness, and tenderness (each with 25\%) (Turhan et al., 2014).

\section{Determination of $p H$ value and TBARS content}

The $\mathrm{pH}$ values of the stored beef patties were determined in homogenates composed of $10 \mathrm{~g}$ of sample and $100 \mathrm{~mL}$ of distilled water. Readings were taken with a digital $\mathrm{pH}$-meter (Cyberscan PC 510 , Singapore) at room temperature, and $\mathrm{pH}$ meter calibration was regularly checked.

The TBARS content of the stored beef patties was determined according to the method described by Witte et al. (1970), with a slight modification. Briefly, to $10 \mathrm{~g}$ of the beef patty sample, $25 \mathrm{~mL}$ of $20 \%$ trichloroacetic acid was added, and the mixture was homogenized with a homogenizer (Ultraturrax-IKA, T25 model, Germany) for $2 \mathrm{~min}$. The homogenates were filtered through Whatman No.1 filter paper. Then, $5 \mathrm{~mL}$ of $0.02 \mathrm{M} 2$-thiobarbituric acid (TBA) solution was added to $5 \mathrm{~mL}$ of filtrate, heated in boiling water for $30 \mathrm{~min}$, and cooled down with tap water. The absorbance was measured at 532 $\mathrm{nm}$ using a UV-Vis spectrophotometer (Agilent Technologies, Cary 60 model, Australia) against a blank containing $5 \mathrm{~mL}$ of $20 \%$ trichloroacetic acid and $5 \mathrm{~mL}$ of $0.02 \mathrm{M}$ TBA solution. Further, a standard curve was plotted using the compound 1,1,3,3-tetraethoxypropane, and the results obtained were expressed as $\mathrm{mg}$ malonaldehyde (MA)/kg sample.

\section{Determination of instrumental color}

Instrumental color was measured on the surface of the stored beef patties using a colorimeter (Minolta Chronometer CR-400, Japan). Five patties per batch were randomly selected and three readings were taken from each patty. Color measurement included Hunter $L, a$, and $b$ parameters, where $L$ represents lightness with a scale from 0 (black) to 100 (white), $a$ represents redness with a scale from -60 (green) to +60 (red), and $b$ represents yellowness with a scale from -60 (blue) to +60 (yellow).

\section{Statistical analysis}

The data were analyzed with the SPSS 21 statistical software (IBM, Chicago, IL, USA), and first checked for normal distribution and homogeneity of variances. The obtained data from proximate composition, cooking loss, texture and sensory evaluation were analyzed by one-way ANOVA, while data from pH, TBARS, and color parameters were analyzed by two-way ANOVA. When the ANOVA was significant $(P$ $<0.05)$, differences between means were compared using Duncan's multiple range test. All results were expressed as mean values \pm standard deviations.

\section{RESULTS AND DISCUSSION}

\section{Total phenolic content and antioxidant activity of pennyroyal powder}

Phenolic compounds, which are abundantly found in plants and change depending on genetic and environmental factors, as well as on postharvest processing conditions, constitute one of the major groups of compounds acting as primary antioxidants or free radical terminators (Shahidi 
and Ambigaipalan, 2015). Therefore, it is important to determine the phenolic content of plants used in food applications as antioxidants. In this study, total phenolic content in the pennyroyal powder was $44.60 \mathrm{mg} \mathrm{GAE} / \mathrm{g}$, and the antioxidant capacity measured by DPPH scavenging activity and FRAP was 744.91 and $73.89 \mathrm{mmol} \mathrm{TE} / \mathrm{g}$, respectively (Table 1).

Table 1. Total phenolic content and antioxidant capacity of pennyroyal powder ${ }^{1}$

\begin{tabular}{lc}
\hline Parameters & Values \\
\hline Total phenolic content (mg GAE/g) & $44.60 \pm 0.39$ \\
DPPH scavenging activity (mmol TE/g) & $744.91 \pm 36.44$ \\
Ferric reducing antioxidant power (FRAP) (mmol TE/g) & $73.89 \pm 1.84$ \\
\hline
\end{tabular}

${ }^{1}$ Values are presented as the mean \pm standard deviation of duplicate samples.

A similar phenolic content was recorded by Gülçin et al. (2020) in methanol extract of pennyroyal, while higher phenolic content was recorded by Gülçin et al. (2020) in water extract and Çelik et al. (2017) in methanol extract. Also, similar to our findings, various authors reported that pennyroyal extracts have a strong antioxidant capacity (Teixeira et al., 2012; Çelik et al., 2017; Gülçin et al., 2020). The phenolic content and antioxidant activity of pennyroyal extracts are extremely variable due to different factors including the extraction temperature, time, $\mathrm{pH}$, solvent polarity, as well as the above-mentioned (Gülçin et al., 2020). These findings show that pennyroyal powder could be a good source of natural antioxidants and use as a natural additive.

\section{Proximate composition and cooking loss of} beef patties with pennyroyal powder

The proximate composition and cooking loss of the beef patties formulated with different levels of pennyroyal powder (P075, P150, P225, and P300) and control samples (CON and $\mathrm{PG}$ ) are given in Table 2. As seen, the addition of pennyroyal powder significantly affected the protein and ash content of beef patties $(P<0.05)$ whereas its effect on moisture, and fat content was not significant $(P>0.05)$.

Table 2. Proximate composition, cooking loss, and texture parameters of beef patties formulated with different levels of pennyroyal powder ${ }^{1}$

\begin{tabular}{lcccccc}
\hline Parameters & \multicolumn{5}{c}{ Batches } \\
\hline & CON $^{2}$ & PG $^{3}$ & P075 & P1505 & P225 & P3007 \\
\hline Moisture (\%) & $50.96 \pm 1.29^{\mathrm{a}}$ & $52.16 \pm 0.80^{\mathrm{a}}$ & $49.81 \pm 0.71^{\mathrm{a}}$ & $50.11 \pm 0.97^{\mathrm{a}}$ & $48.33 \pm 0.42^{\mathrm{a}}$ & $48.81 \pm 1.26^{\mathrm{a}}$ \\
Protein (\%) & $18.86 \pm 0.28^{\mathrm{a}}$ & $18.76 \pm 0.45^{\mathrm{a}}$ & $17.84 \pm 0.35^{\mathrm{ab}}$ & $17.37 \pm 0.25^{\mathrm{bc}}$ & $15.96 \pm 0.01^{\mathrm{d}}$ & $16.46 \pm 0.72^{\mathrm{cd}}$ \\
Fat (\%) & $26.54 \pm 0.76^{\mathrm{a}}$ & $27.51 \pm 0.11^{\mathrm{a}}$ & $27.41 \pm 0.00^{\mathrm{a}}$ & $27.09 \pm 0.84^{\mathrm{a}}$ & $27.50 \pm 0.70^{\mathrm{a}}$ & $27.50 \pm 0.70^{\mathrm{a}}$ \\
Ash (\%) & $2.45 \pm 0.04^{\mathrm{d}}$ & $2.49 \pm 0.08^{\mathrm{d}}$ & $2.54 \pm 0.00^{\mathrm{cd}}$ & $2.65 \pm 0.06^{\mathrm{bc}}$ & $2.74 \pm 0.00^{\mathrm{b}}$ & $2.94 \pm 0.05^{\mathrm{a}}$ \\
Cooking loss (\%) & $28.57 \pm 0.42^{\mathrm{a}}$ & $28.00 \pm 0.42^{\mathrm{ab}}$ & $27.28 \pm 0.40^{\mathrm{b}}$ & $27.39 \pm 0.28^{\mathrm{b}}$ & $25.08 \pm 0.14^{\mathrm{c}}$ & $22.33 \pm 0.28^{\mathrm{d}}$ \\
Hardness (N) & $86.84 \pm 1.28^{\mathrm{d}}$ & $94.13 \pm 2.34^{\mathrm{c}}$ & $101.31 \pm 2.82^{\mathrm{b}}$ & $95.51 \pm 4.55^{\mathrm{bc}}$ & $117.45 \pm 2.82^{\mathrm{a}}$ & $116.36 \pm 1.10^{\mathrm{a}}$ \\
Springiness (mm) & $0.55 \pm 0.02^{\mathrm{b}}$ & $0.65 \pm 0.04^{\mathrm{ab}}$ & $0.67 \pm 0.04^{\mathrm{a}}$ & $0.69 \pm 0.04^{\mathrm{a}}$ & $0.65 \pm 0.01^{\mathrm{ab}}$ & $0.74 \pm 0.05^{\mathrm{a}}$ \\
Cohesiveness & $0.23 \pm 0.01^{\mathrm{a}}$ & $0.24 \pm 0.01^{\mathrm{a}}$ & $0.25 \pm 0.01^{\mathrm{a}}$ & $0.24 \pm 0.01^{\mathrm{a}}$ & $0.24 \pm 0.01^{\mathrm{a}}$ & $0.24 \pm 0.01^{\mathrm{a}}$ \\
Chewiness (N.mm) & $10.80 \pm 0.56^{\mathrm{d}}$ & $14.58 \pm 1.56^{\mathrm{c}}$ & $17.18 \pm 0.70^{\mathrm{bc}}$ & $16.33 \pm 2.02^{\mathrm{bc}}$ & $18.26 \pm 1.41^{\mathrm{b}}$ & $22.36 \pm 1.52^{\mathrm{a}}$ \\
\hline
\end{tabular}

${ }^{1}$ Values are presented as the mean \pm standard deviation of duplicate samples. Means not sharing a common superscript a, b, c or d in a row are significantly different at $P<0.05$ as assessed by Duncan's multiple range test. ${ }^{2} \mathrm{CON}$ - negative control sample.

${ }^{3} \mathrm{PG}$ - positive control sample with $0.01 \%$ propyl gallate.

${ }^{4} \mathrm{P} 075$ - sample with $0.75 \%$ pennyroyal powder.

${ }^{5} \mathrm{P} 150$ - sample with $1.5 \%$ pennyroyal powder.

${ }^{6} \mathrm{P} 225$ - sample with $2.25 \%$ pennyroyal powder.

${ }^{7} \mathrm{P} 300$ - sample with $3.0 \%$ pennyroyal powder. 
The protein content of patties gradually decreased with an increase in pennyroyal powder level, but the ash content increased. The decrease in protein content could result from the dilution effect because the protein content in the pennyroyal powder was lower than in the minced beef. Similarly, Bilek and Turhan (2009) reported a decrease in the protein content of beef patties formulated with different levels of flaxseed flour. Also, Aykin Dinçer et al. (2018) observed a concomitant decrease in protein content in meatballs formulated with retrograded flour. The increase in ash content could be attributable to the high ash content $(10.63 \%)$ of pennyroyal powder. It was also stated in previous studies that the addition of plant materials containing high amounts of ash to beef patties could increase the ash content of products (Bilek and Turhan, 2009; Alakali et al., 2010; Ran et al., 2020). Despite these changes in protein and ash content, the moisture, protein and fat contents of all beef patties were within the limits of the Turkish Uncooked Meatball Standard (TSE 10581, 2007).

The addition of pennyroyal powder significantly affected the cooking loss of beef patties $(P<0.05)$ and the cooking loss gradually decreased with more pennyroyal powder addition (Table 2). Turhan et al. (2005) reported that cooking losses were due to loss of fat and evaporation of moisture during the cooking process. The improvement in cooking performance with pennyroyal powder addition could attributed to its high ability to keep moisture and fat in patty matrix. Various researchers also reported that addition of non-meat ingredients to patty formulation reduce the cooking losses. For example, Turhan et al. (2005) reported decreased cooking loss in beef burgers formulated with different levels of hazelnut pellicle. Similarly, Alakali et al. (2010) also observed that addition of bambara groundnut (Vigna subterranean L.) seed flour to beef patties resulted in better cooking yield.

\section{Texture parameters of beef patties with pennyroyal powder}

As seen in Table 2, the addition of pennyroyal powder to formulation significantly affected the hardness, springiness, and chewiness $(P<0.05)$ whereas its effect on cohesiveness was not significant $(P>0.05)$. A progressive increase in the pennyroyal powder level remarkably increased the hardness and chewiness values of beef patties but slightly increased the springiness values. However, no significant differences were observed among springiness values of beef patties with pennyroyal powder at different levels. The increase in hardness, springiness, and chewiness with pennyroyal powder addition might be due to the decreasing moisture content (Table 2) with increased levels of pennyroyal powder. Namely, a higher amount of pennyroyal powder may contribute to higher dry matter content which therefore resulted in beef patties with greater hardness and chewiness. It was also reported in previous studies that the addition of plant materials containing high amounts of dry matter to beef patties increases the hardness and chewiness of products (Huang et al., 2005; Aykin Dinçer et al., 2018; Ran et al., 2020). In addition, high-fiber ingredients added to patties can also increase the hardness (Saraiva et al., 2019).

\section{Sensory attributes of beef patties with pennyroyal powder}

The incorporation of pennyroyal powder at different levels to beef patties significantly affected the appearance, flavor, and overall acceptability $(P<0.05)$ whereas its effect on juiciness and tenderness was not significant $(P$ $>0.05$ ), as shown in Fig. 1.

Generally, the highest appearance, flavor, and overall acceptability scores were observed in the CON and PG samples, and the scores decreased with more pennyroyal powder addition. However, the addition of pennyroyal powder to beef patties at a level up to $1.5 \%$ did not affect the flavor and overall acceptability compared to CON and PG, while even the addition of pennyroyal powder level to $0.75 \%$ resulted a slightly greenish color and this state was probably evaluated with the lower score by the panelists. Finally, the lowest flavor, appearance, and overall acceptability scores were noticed in P225 and P300 patties due to an intense mint flavor and greenish color formation after high-level pennyroyal powder 
addition. Such negative effects of the use of nonmeat ingredients at high levels on the sensory properties of comminuted meat products were also reported by many authors. For example, Turhan et al. (2005) reported that overall acceptability scores of beef burgers formulated with different levels of hazelnut pellicle were decreased as the pellicle content increased due to less mastication and mask the meat flavor. Similarly, Bilek and Turhan (2009) found that the sensory scores of beef patties decreased as the flaxseed content increased and this decrease was higher with more than $6 \%$ flaxseed flour addition. Therefore, $1.5 \%$ of pennyroyal powder is considered optimum for use an enhancer to the nutritive value in beef patties.

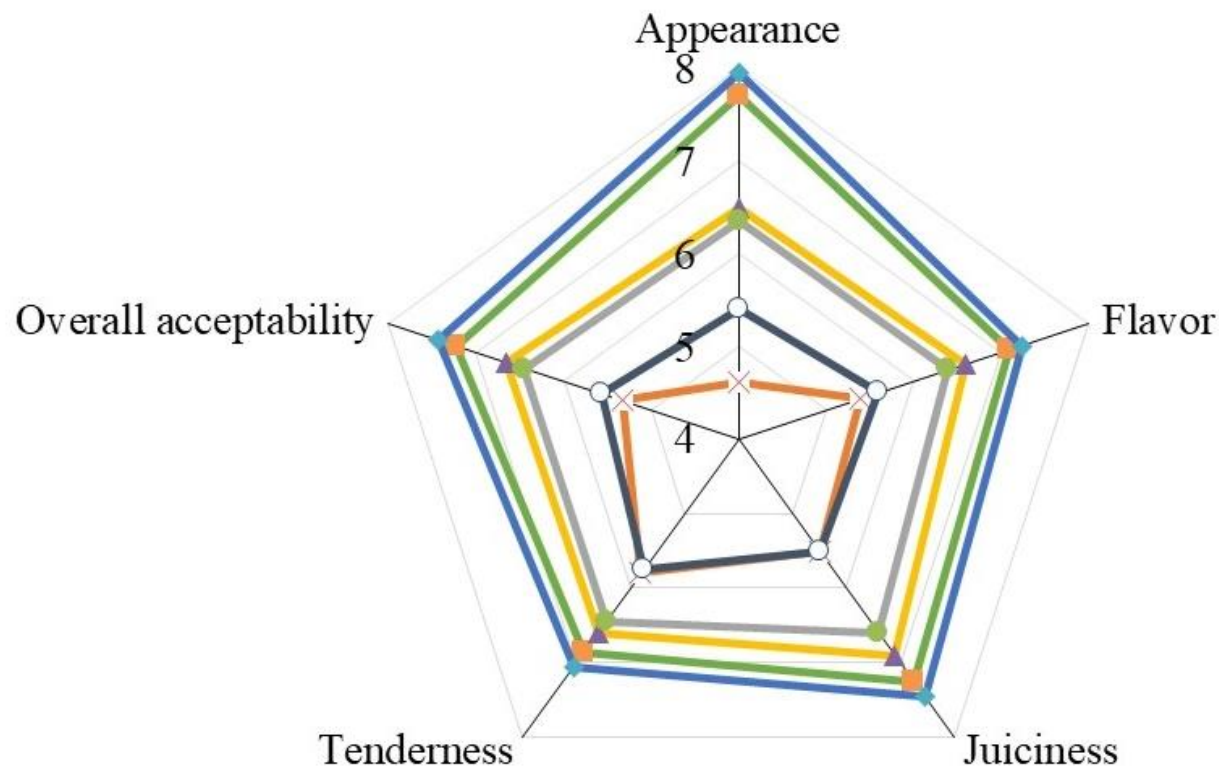

$\rightarrow$-CON - negative control sample

^P075 - sample with $0.75 \%$ pennyroyal powder

$\rightarrow$ P150 - sample with $1.5 \%$ pennyroyal powder

- $\times$ P 225 - sample with $2.25 \%$ pennyroyal powder

- - P300 - sample with $3.0 \%$ pennyroyal powder

Figure 1. Sensory scores of beef patties formulated with different levels of pennyroyal powder

pH and TBARS values of beef patties with pennyroyal powder during storage

The $\mathrm{pH}$ and TBARS values of the beef patties formulated with different levels of pennyroyal powder during storage at $4{ }^{\circ} \mathrm{C}$ are given in Table 3. As seen, the initial $\mathrm{pH}$ values of beef patty samples ranged from 5.84 to 5.93 , and on days 0 and 3 of storage, the differences between $\mathrm{pH}$ values of samples were not significantly different $(P>0.05)$. However, the $\mathrm{pH}$ values of all samples gradually increased after day 3 of storage, and the highest $\mathrm{pH}$ values were recorded in the $\mathrm{CON}$ patty samples which increased from 5.69 on day 3 to 7.10 on day 9 followed by the pH of PG beef patties presenting $\mathrm{pH}$ values ranging from 5.78 to 7.04 on $3^{\text {td }}$ day and on $9^{\text {th }}$ day, respectively. Thus, propyl gallate as synthetic antioxidants did not show any effect on $\mathrm{pH}$. The pennyroyal powder addition to beef patties significantly $(P<0.05)$ slowed the rate of $\mathrm{pH}$ increase and on days 6 and 9 of storage, P225, and P300 patties exhibited the lowest $\mathrm{pH}$ values. Consequently, the addition of pennyroyal powder significantly enhanced the $\mathrm{pH}$ stability of the patties simultaneously with the 
level of pennyroyal powder suggesting the protective role of pennyroyal against spoilage microorganisms. The increase in $\mathrm{pH}$ could be due to the degradation of nitrogenous components in beef patties during the storage period. This process was directly influenced by the action of endogenous or microbial enzymes such as proteases or lipases (Danowska-Oziewicz and Kurp, 2017; Morsy et al., 2018; Villasante et al.,
2020). Similarly, Ikhlas et al. (2012) reported an increase in the $\mathrm{pH}$ value in Cosmos caudatus, Polygonum minus, and BHT treated quail meatballs during the refrigeration storage. Also, Villasante et al. (2020) reported a significant increase in the $\mathrm{pH}$ of beef patties including different combinations of pecan shells, rosella flowers, and red pepper during the storage period.

Table 3. Changes in $\mathrm{pH}$ and TBARS values of beef patties formulated with different levels of pennyroyal powder during storage at $4{ }^{\circ} \mathrm{C}^{1}$

\begin{tabular}{|c|c|c|c|c|c|}
\hline \multirow[t]{2}{*}{ Parameters } & \multirow[t]{2}{*}{ Batches } & \multicolumn{4}{|c|}{ Storage period (days) } \\
\hline & & 0 & 3 & 6 & 9 \\
\hline \multirow[t]{6}{*}{$\mathrm{pH}$} & $\mathrm{CON}^{2}$ & $5.87 \pm 0.17^{\mathrm{aC}}$ & $5.69 \pm 0.27^{\mathrm{aC}}$ & $6.38 \pm 0.07 \mathrm{bB}$ & $7.10 \pm 0.14^{\mathrm{aA}}$ \\
\hline & $\mathrm{PG}^{3}$ & $5.84 \pm 0.21^{\mathrm{aC}}$ & $5.78 \pm 0.27^{\mathrm{aC}}$ & $6.36 \pm 0.03^{\mathrm{bB}}$ & $7.04 \pm 0.16^{\mathrm{abA}}$ \\
\hline & P0754 & $5.91 \pm 0.18^{\mathrm{aC}}$ & $5.68 \pm 0.18^{\mathrm{aC}}$ & $6.57 \pm 0.09^{\mathrm{aB}}$ & $6.84 \pm 0.24^{\mathrm{abA}}$ \\
\hline & P1505 & $5.93 \pm 0.13^{\mathrm{aC}}$ & $5.53 \pm 0.11^{\mathrm{aD}}$ & $6.33 \pm 0.27 \mathrm{bB}$ & $6.77 \pm 0.30^{\mathrm{bA}}$ \\
\hline & $\mathrm{P} 225^{6}$ & $5.85 \pm 0.02^{\mathrm{aB}}$ & $5.58 \pm 0.05^{\mathrm{aC}}$ & $5.85 \pm 0.02^{\mathrm{cB}}$ & $6.08 \pm 0.01 \mathrm{cA}$ \\
\hline & $\mathrm{P} 300^{7}$ & $5.85 \pm 0.02^{\mathrm{aB}}$ & $5.61 \pm 0.01^{\mathrm{aD}}$ & $5.74 \pm 0.05^{\mathrm{cC}}$ & $5.99 \pm 0.01^{\mathrm{cA}}$ \\
\hline \multirow{6}{*}{$\begin{array}{l}\text { TBARS } \\
(\mathrm{mg} \text { MDA/kg) }\end{array}$} & $\mathrm{CON}^{2}$ & $1.43 \pm 0.56^{\mathrm{aC}}$ & $3.36 \pm 0.13^{\mathrm{aAB}}$ & $3.12 \pm 0.86^{\mathrm{aB}}$ & $4.06 \pm 0.51^{\mathrm{aA}}$ \\
\hline & $\mathrm{PG}^{3}$ & $0.73 \pm 0.46^{\mathrm{bB}}$ & $1.00 \pm 0.16^{\mathrm{dB}}$ & $1.50 \pm 0.31^{\mathrm{bA}}$ & $1.76 \pm 0.14^{\mathrm{cA}}$ \\
\hline & $\mathrm{P} 075^{4}$ & $1.35 \pm 0.17^{\mathrm{aB}}$ & $1.29 \pm 0.10^{\mathrm{cdB}}$ & $1.63 \pm 0.41^{\mathrm{bB}}$ & $2.32 \pm 0.19 \mathrm{bA}$ \\
\hline & P1505 & $1.77 \pm 0.22^{\mathrm{aB}}$ & $1.26 \pm 0.07 \mathrm{cdC}$ & $1.37 \pm 0.17 \mathrm{bBC}$ & $2.61 \pm 0.53^{\mathrm{bA}}$ \\
\hline & $\mathrm{P} 225^{6}$ & $1.39 \pm 0.43^{\mathrm{aB}}$ & $2.50 \pm 0.10^{\mathrm{bA}}$ & $1.78 \pm 0.20^{\mathrm{bB}}$ & $1.79 \pm 0.17 \mathrm{cB}$ \\
\hline & $\mathrm{P} 300^{7}$ & $1.85 \pm 0.19^{\mathrm{aAB}}$ & $1.54 \pm 0.44^{\mathrm{cC}}$ & $1.71 \pm 0.76^{\mathrm{bAB}}$ & $2.41 \pm 0.27^{\mathrm{bA}}$ \\
\hline
\end{tabular}

${ }^{1}$ Values are presented as the mean \pm standard deviation of duplicate samples. Means not sharing a common superscript a, b, $\mathrm{c}$ or $\mathrm{d}$ in a column or $\mathrm{A}, \mathrm{B}, \mathrm{C}$ or $\mathrm{D}$ in a row are significantly different at $P<0.05$ as assessed by Duncan's multiple range test.

${ }^{2} \mathrm{CON}$ - negative control sample.

3PG - positive control sample with $0.01 \%$ propyl gallate. ${ }^{4} \mathrm{P} 075$ - sample with $0.75 \%$ pennyroyal powder.

${ }^{5} \mathrm{P} 150$ - sample with $1.5 \%$ pennyroyal powder.

${ }^{6} \mathrm{P} 225$ - sample with $2.25 \%$ pennyroyal powder.

${ }^{7} \mathrm{P} 300$ - sample with $3.0 \%$ pennyroyal powder.

As seen in Table 3, the addition of pennyroyal powder showed a significant effect on TBARS of beef patties $(P<0.05)$. At the beginning of storage, the lowest TBARS value was determined in the PG samples $(P<0.05)$, while $\mathrm{CON}$ and patties containing pennyroyal powder exhibited similar TBARS values $(P>0.05)$; however, the PG and patties containing pennyroyal powder revealed a noticeable decrease in TBARS value compared to the CON samples in other storage periods $(P<0.05)$. On day 9 of storage, the TBARS values of all patty samples increased compared to the beginning of storage, but the rate of increase was considerably slower in PG and beef patties containing pennyroyal powder compared to the CON samples. On day 9 of storage, the lowest TBARS values were determined in PG and P225 samples. Similarly, other patty samples containing pennyroyal powder also exhibited lower TBARS value than the CON samples, thus indicating high protection of pennyroyal powder against lipid oxidation in beef patties. These results are also supported by phenolic content and antioxidant capacity results of pennyroyal powder (Table 1). The antioxidative effect of pennyroyal powder could be explained by phenolics such as kaempferol-3O-rutinoside, quercetagetin-3,6-dimethylether, 
fumaric acid, chlorogenic acid, apigenin, and epicatechin present in pennyroyal. These phenolic components have multifunctional properties and can act as ROS scavengers, singlet oxygen scavengers, reducing agents, and hydrogen atom donators. Additionally, phenolics especially flavonoids are capable of metal chelating and reducing abilities (Gülçin et al., 2020). Similarly, Kamkar et al. (2010) observed that water and methanol extracts of Mentha pulegium are able to inhibit both primary and secondary oxidation of sunflower oil during storage.

P075 and P150 on $3^{\text {rd }}$ day, all patties containing pennyroyal on $6^{\text {th }}$ day, and P225 on $9^{\text {th }}$ day of storage showed similar TBARS values to those treated with PG $(P>0.05)$ (Table 3). Similar to our results, Kamkar et al. (2010) reported that the protection offered by water and methanol extracts of Mentha pulegium is comparable to widely used synthetic antioxidant BHT and it can be added to the commercial vegetable oils as a natural antioxidant. Therefore, the present study results indicate that pennyroyal powder can be considered as a natural antioxidant to prevent lipid oxidation in beef patties.

\section{Instrumental color parameters of beef patties with pennyroyal powder during storage}

The instrumental color parameters of the beef patties formulated with pennyroyal powder during storage at $4{ }^{\circ} \mathrm{C}$ are given in Table 4 . As seen, the addition of pennyroyal powder showed a significant effect on $L, a$ and $b$ values of the samples $(P<0.05)$.

Table 4. Changes in color parameters of beef patties formulated with different levels of pennyroyal powder during storage at $4{ }^{\circ} \mathrm{C}^{1}$

\begin{tabular}{|c|c|c|c|c|c|}
\hline \multirow[t]{2}{*}{ Parameters } & \multirow[t]{2}{*}{ Batches } & \multicolumn{4}{|c|}{ Storage period (days) } \\
\hline & & 0 & 3 & 6 & 9 \\
\hline \multirow[t]{6}{*}{$L$} & $\mathrm{CON}^{2}$ & $42.51 \pm 3.47 \mathrm{aA}$ & $45.08 \pm 3.82^{\mathrm{aA}}$ & $43.37 \pm 3.11^{\mathrm{aA}}$ & $42.26 \pm 5.53^{\mathrm{aA}}$ \\
\hline & $\mathrm{PG}^{3}$ & $44.74 \pm 4.41^{\mathrm{aA}}$ & $44.13 \pm 3.66^{\mathrm{abA}}$ & $41.39 \pm 2.34 \mathrm{bA}$ & $42.26 \pm 1.61^{\mathrm{aA}}$ \\
\hline & $\mathrm{P} 075^{4}$ & $43.79 \pm 1.52^{\mathrm{aA}}$ & $41.92 \pm 0.44^{\mathrm{bB}}$ & $38.30 \pm 0.84^{\mathrm{cC}}$ & $37.65 \pm 0.85^{\mathrm{bC}}$ \\
\hline & P1505 & $39.31 \pm 3.04^{\mathrm{bA}}$ & $38.03 \pm 2.75^{\mathrm{cAB}}$ & $36.63 \pm 2.14^{\mathrm{cB}}$ & $35.91 \pm 1.46^{\mathrm{bB}}$ \\
\hline & P2256 & $39.14 \pm 1.40^{\mathrm{bA}}$ & $37.68 \pm 0.69 \mathrm{cB}$ & $36.50 \pm 1.13^{\mathrm{cC}}$ & $35.61 \pm 0.85^{\mathrm{bC}}$ \\
\hline & $\mathrm{P} 300^{7}$ & $35.87 \pm 2.60 \mathrm{cA}$ & $33.69 \pm 2.94 \mathrm{dAB}$ & $34.38 \pm 2.51 \mathrm{dAB}$ & $32.63 \pm 1.48^{\mathrm{cB}}$ \\
\hline \multirow[t]{6}{*}{$a$} & $\mathrm{CON}^{2}$ & $15.16 \pm 1.19 \mathrm{bA}$ & $12.17 \pm 3.87 \mathrm{aB}$ & $14.15 \pm 2.03 \mathrm{aAB}$ & $12.36 \pm 1.88^{\mathrm{aB}}$ \\
\hline & $\mathrm{PG}^{3}$ & $16.34 \pm 1.66^{\mathrm{aA}}$ & $11.23 \pm 1.99 \mathrm{aB}$ & $11.22 \pm 2.02^{\mathrm{bB}}$ & $10.04 \pm 2.82^{\mathrm{bB}}$ \\
\hline & $\mathrm{P} 075^{4}$ & $9.58 \pm 0.79 \mathrm{cA}$ & $3.89 \pm 0.55^{\mathrm{bC}}$ & $7.26 \pm 1.13 \mathrm{cB}$ & $7.13 \pm 1.91$ св \\
\hline & $\mathrm{P} 150^{5}$ & $3.82 \pm 0.34 \mathrm{~dB}$ & $2.96 \pm 0.50^{\mathrm{bC}}$ & $5.10 \pm 1.37 \mathrm{dA}$ & $5.71 \pm 0.81 \mathrm{cA}$ \\
\hline & $\mathrm{P} 225^{6}$ & $3.25 \pm 0.31 \mathrm{~dB}$ & $2.62 \pm 0.37 \mathrm{bc}$ & $2.83 \pm 0.37 \mathrm{eC}$ & $3.92 \pm 0.63^{\mathrm{dA}}$ \\
\hline & $\mathrm{P} 300^{7}$ & $1.93 \pm 0.32^{\mathrm{eB}}$ & $2.15 \pm 0.34 \mathrm{bB}$ & $3.26 \pm 0.45^{\mathrm{eA}}$ & $3.30 \pm 0.49 \mathrm{dA}$ \\
\hline \multirow[t]{6}{*}{$b$} & $\mathrm{CON}^{2}$ & $11.31 \pm 1.05^{\mathrm{abA}}$ & $10.49 \pm 1.16^{\mathrm{ab} A B}$ & $9.57 \pm 1.05^{\mathrm{aBC}}$ & $8.83 \pm 0.97 \mathrm{cC}$ \\
\hline & $\mathrm{PG}^{3}$ & $12.04 \pm 1.03 \mathrm{aA}$ & $10.28 \pm 1.17 \mathrm{abB}$ & $8.43 \pm 1.67 \mathrm{bC}$ & $7.65 \pm 1.28 \mathrm{dC}$ \\
\hline & P0754 & $11.67 \pm 0.54 \mathrm{abA}$ & $11.16 \pm 0.77 \mathrm{aB}$ & $9.72 \pm 0.24 \mathrm{aC}$ & $9.53 \pm 0.39 \mathrm{bcC}$ \\
\hline & $\mathrm{P} 150^{5}$ & $10.90 \pm 0.76^{\mathrm{bcA}}$ & $10.72 \pm 0.84 \mathrm{aA}$ & $10.01 \pm 0.53^{\mathrm{aB}}$ & $10.41 \pm 0.39 \mathrm{aAB}$ \\
\hline & P2256 & $11.35 \pm 0.41^{\mathrm{abA}}$ & $10.42 \pm 0.21 \mathrm{abB}$ & $10.07 \pm 0.31^{\mathrm{aC}}$ & $9.67 \pm 0.34^{\mathrm{bD}}$ \\
\hline & $\mathrm{P} 300^{7}$ & $10.31 \pm 0.80^{\mathrm{cA}}$ & $9.65 \pm 0.88^{\mathrm{bAB}}$ & $9.77 \pm 0.79 \mathrm{aAB}$ & $9.19 \pm 0.71 \mathrm{bcB}$ \\
\hline
\end{tabular}

${ }^{1}$ Values are presented as the mean \pm standard deviation of duplicate samples. Means not sharing a common superscript a, b, c, d or e in a column or A, B, C or D in a row are significantly different at $P<0.05$ as assessed by Duncan's multiple range test.

${ }^{2} \mathrm{CON}$ - negative control sample.

${ }^{3} \mathrm{PG}$ - positive control sample with $0.01 \%$ propyl gallate.

${ }^{4} \mathrm{P} 075$ - sample with $0.75 \%$ pennyroyal powder.

${ }^{5} \mathrm{P} 150$ - sample with $1.5 \%$ pennyroyal powder.

${ }^{6} \mathrm{P} 225$ - sample with $2.25 \%$ pennyroyal powder.

${ }^{7} \mathrm{P} 300$ - sample with $3.0 \%$ pennyroyal powder. 
The incorporation of different levels of pennyroyal powder to beef patties reduced the lightness $(L)$ and redness (a) values of formulated patties compared to the CON and PG, and values further reduced with increasing pennyroyal powder level. Thus, the beef patties formulated with more pennyroyal powder became darker and greenish in color. This decline in lightness and redness could be attributed to the natural color of pennyroyal powder, ranging from light green to deep green, which depends on drying conditions. Similarly, Choe et al. (2011) reported that the addition of lotus leaf (Nelumbo nucifera) powder and barley leaf (Hordeum vulgare) powder to raw minced pork caused lower $L$ and $a$ values compared to the control samples over the storage time. While $L$ values of CON and PG samples did not change during storage, those of beef patties containing pennyroyal powder decreased. This decrease could be related to the presence of antioxidant compounds in pennyroyal powder retarding metmyoglobin formation in beef patties. However, the $a$ values of the CON, PG and P075 samples decreased compared to the beginning of the storage but those of samples containing pennyroyal powder slightly increased. Like the lightness results, the redness values also confirm that the antioxidant compounds in pennyroyal powder retarded myoglobin oxidation. On day 9 of storage, all beef patty samples exhibited lower $b$ values compared to the beginning of storage. Similar results were also reported by various authors (Hawashin et al., 2016; Prommachart et al., 2020; Bellucci et al., 2021).

\section{CONCLUSION}

Our findings showed that the pennyroyal powder is a natural source of phenolic compounds and has potent antioxidant properties in two bioanalytical assays including DPPH scavenging activity and FRAP. Although the addition of pennyroyal powder to beef patties decreased the protein content and increased the ash content, the proximate composition of all patties was within the limits of the Turkish Uncooked Meatball Standard (TSE 10581, 2007). The inclusion of pennyroyal powder to the beef patties improved cooking loss, but adversely affect the hardness and overall acceptability. However, the addition of pennyroyal powder to beef patties at a level up to $1.5 \%$ did not affect the flavor and overall acceptability compared to control samples. Also, the addition of pennyroyal powder into beef patties improved the $\mathrm{pH}$, lipid, and color stability during 9 days of cold storage. Thus, pennyroyal powder could be used in beef patties at 1.5\% concentration to retard the lipid and color oxidation with minimal compositional, textural, and sensory changes.

\section{CONFLICT OF INTEREST}

There are no possible conflicts of interest between the authors.

\section{AUTHOR CONTRIBUTION}

This study was derived from Farida Guliyeva's Master's thesis and Sadettin Turhan contributed as the thesis supervisor in conducting analyzes, statistical analyses of data, writing the article, and writing-review-proofreading-publishing

procedures. The Master's thesis student Farida Guliyeva carried out the preparation of samples, analyses, reporting, and writing and correction of literature sources. The authors have read and approved the final version of the article.

\section{REFERENCES}

Alakali, J.S., Irtwange, S.V., Mzer, M.T. (2010). Quality evaluation of beef patties formulated with bambara groundnut (Vigna subterranean L.) seed flour. Meat Sci, 85: 215-223.

AOAC (2000). Official methods of analysis (16th ed.). Association of Official Analytical Chemists, AOAC International, Washington, DC.

Aykin Dinçer, E., Kiliç Büyükkurt, Ö., Candal, C., Bilgiç, B.F., Erbaş, M. (2018). Investigation of the usability of retrograded flour in meatball production as a structure enhancer. Korean J Food Sci An, 38: 78-87.

Bellucci, E.R.B., Munekata, P.E.S., Pateiro, M., Lorenzo, J.M., Barretto, A.C.S. (2021). Red pitaya extract as natural antioxidant in pork patties with total replacement of animal fat. Meat Sci, 171: 108284. 
Bilek, A.E., Turhan, S. (2009). Enhancement of the nutritional status of beef patties by adding flaxseed flour. Meat Sci, 82: 472-477.

Choe, J.H., Choi, J.H., Choi, Y.S., Han, D.J., Kim, H.Y., Lee, M.A., Kim, S.Y., Kim, C.J. (2011). Antioxidant properties of lotus leaf (Nelumbo nucifera) powder and barley leaf (Hordeum vulgare) powder in raw minced pork during chilled storage. Korean J Food Sci An, 31(1): 32-39.

Çelik, S.E., Tufan, A.N., Bekdeşer, B., Özyürek, M., Güçlü, K., Apak, R. (2017). Identification and Determination of Phenolics in Lamiaceae Species by UPLC-DAD-ESI-MS/MS. J Chromatogr Sci, 55(3): 291-300.

Danowska-Oziewicz, M., Kurp, L. (2017). Physicochemical properties, lipid oxidation and sensory attributes of pork patties with lupin protein concentrate stored in vacuum, modified atmosphere and frozen state. Meat Sci, 131: 158165.

Fernandez-Lopez, J., Zhi, N., Aleson-Carbonell, L., Perez-Alvarez, J.A., Kuri, V. (2005). Antioxidant and antibacterial activities of natural extracts: Application in beef meatballs. Meat Sci, 69: 371-380.

Gao, X., Björk, L., Trajkovski, V., Uggla, M. (2000). Evaluation of antioxidant actives of rosehip ethanol extracts in different test systems. J Agric Food Chem, 80: 2021-2027.

Gülçin, İ., Gören, A., Taslimi, P., Alwasel, S.H., Kilıc, O., Bursal, E. (2020). Anticholinergic, antidiabetic and antioxidant activities of Anatolian pennyroyal (Mentha pulegium)-analysis of its polyphenol contents by LC-MS/MS. Biocatal Agric Biotechnol, 23: 101441.

Hautrive, T.P., Piccolo, J., Rodrigues, A.S., Campagnol, P.C.B., Kubota, E.H. (2019). Effect of fat replacement by chitosan and golden flaxseed flour (wholemeal and defatted) on the quality of hamburgers. LWT - Food Sci Technol, 102: 403-410.

Hawashin, M.D., Al-Juhaimi, F., Ahmed, I.A.M., Ghafoor, K., Babiker, E.E. (2016). Physicochemical, microbiological and sensory evaluation of beef patties incorporated with destoned olive cake powder. Meat Sci, 122: 32-39.

Huang, S.C., Shiau, C.Y., Liu, T.E., Chu, C.L., Hwang, D.F. (2005). Effects of rice bran on sensory and physico-chemical properties of emulsified pork meatballs. Meat Sci, 70(4): 613619.

Ikhlas, B., Huda, N., Ismail, N. (2012). Effect of Cosmos caudatus, Polygonum minus and BHT on physical properties, oxidative process, and microbiology growth of quail meatball during refrigeration storages. J Food Process Preserv, 36: 5566.

Juntachote, T., Berghofer, E., Siebenhandl, S., Bauer, F. (2006). The oxidative properties of Holy basil and Galangal in cooked ground pork. Meat Sci, 72: 446-456.

Juntachote, T., Berghofer, E., Siebenhandl, S., Bauer, F. (2007). The effect of dried galangal powder and its ethanolic extracts on oxidative stability in cooked ground pork. LWT - Food Sci Technol, 40(2): 324-330.

Kamkar, A., Javan, A.J., Asadi, F., Kamalinejad, M. (2010). The antioxidative effect of Iranian Mentha pulegium extracts and essential oil in sunflower oil. Food Chem Toxicol, 48: 1796-1800.

Morsy, M.K., Mekawi, W., Elsabagh, R. (2018). Impact of pomegranate peel nanoparticles on quality attributes of meatballs during refrigerated storage. LWT - Food Sci Technol, 89: 489-495.

Nakajima, J., Tanaka, I., Seo, S., Yamazaki, M., Saito, K. (2004). LC/PDA/ESI-MS profiling and radical scavenging activity of anthocyanins in various berries. J Biomed Biotechnol, 5: 241-247.

Öztürk, T., Turhan, S. (2020). Physicochemical properties of pumpkin (Cucurbita pepo L.) seed kernel flour and its utilization in beef meatballs as a fat replacer and functional ingredient. $J$ Food Process Preserv, 44(9): e14695.

Prommachart, R., Belem, T.S., Uriyapongson, S., Rayas-Duarte, P., Uriyapongson, J., Ramanathan, R. (2020). The effect of black rice water extract on surface color, lipid oxidation, microbial growth, and antioxidant activity of beef patties during chilled storage. Meat Sci, 164: 108091. 
Ran, M., Chen, C., Li, C., He, L., Zeng, X. (2020). Effects of replacing fat with Perilla seed on the characteristics of meatballs. Meat Sci, 161: 107995.

Saraiva, B.R., Agustinho, B.C., Vital, A.C.P., Staub, L., Pintro, P.T.M. (2019). Effect of brewing waste (malt bagasse) addition on the physicochemical properties of hamburgers. J Food Process Preserv, 43(10): e14135.

Selani, M.M., Shirado, G.A.N., Margiotta, G.B., Rasera, M.L., Marabesi, A.C., Piedade, S.M.S., Contreras-Castillo, C.J., Canniatti-Brazaca, S.G. (2016). Pineapple by-product and canola oil as partial fat replacers in low-fat beef burger: Effects on oxidative stability, cholesterol content and fatty acid profile. Meat $S c i, 115,9-15$.

Shahidi, F., Ambigaipalan, P. (2015). Phenolics and polyphenolics in foods, beverages and spices: Antioxidant activity and health effects - A review. J Funct Foods, 18: Part B, 820-897.

Singleton, V.L., Rossi, J.A. (1965). Colorimetry of total phenolic with phosphomolybdic and phosphotungstic acid reagent. Am J Enol Viticult, 16(3): 144-158.

Teixeira, B., Marques, A., Ramos, C., Batista, I., Serrano, C., Matos, O., Neng, N.R., Nogueira, J.M.F., Saraiva, J.A., Nunes, M.L. (2012).
European pennyroyal (Mentha pulegium) from Portugal: Chemical composition of essential oil and antioxidant and antimicrobial properties of extracts and essential oil. Ind Crops Prod, 36: 81-87.

TSE 10581 (2007). Turkish Uncooked Meatball Standard, TSE 10581. Turkish Standards Institution, Ankara.

Turhan, S., Sagir, I., Ustun, N. S. (2005). Utilization of hazelnut pellicle in low-fat beef burgers. Meat $S_{c i}, 71:$ 312-316.

Turhan, S., Yazici, F., Saricaoglu, F.T., Mortas, M., Genccelep, H. (2014). Evaluation of the nutritional and storage quality of meatballs formulated with bee pollen. Korean J Food Sci An, 34: 423-433.

Villasante, J., Ouerfelli, M., Bobet, A., Metón, I., Almajano, M. P. (2020). The Effects of pecan shell, roselle flower and red pepper on the quality of beef patties during chilled storage. Foods, 9: 1692.

Witte, V.C., Krause, G.F., Bailey, M.E. (1970). A new extraction method for determining 2thiobarbituric acid values of pork and beef during storage. J Food Sci, 35: 582-585. 